\title{
EORA AND ENGLISH AT PORT JACKSON: A SPANISH VIEW
}

\author{
Robert J. King
}

Between 12 March and 11 April 1793, the waters of Sydney Cove, Port Jackson, were graced for the first time by the presence of ships of the Spanish Royal Navy; the corvettes Descubierta and Atrevida, under the command of Captains Alexandro Malaspina and José de Bustamente y Guerra.

The visit to Port Jackson took place as part of a 'scientific and political' voyage of discovery through the South Atlantic and Pacific Oceans planned by Malaspina and Bustamente, and carried out by them during the years 1789 to 1794 .

In the Plan of the voyage, which they submitted to the Minister for the Marine and the Indies, Antonio Valdéz, on 10 September 1788, Malaspina and Bustamente stated that the principal objects were: a thorough investigation of the natural resources of the Spanish possessions in America and the Pacific (the whole of which was claimed at that time as a Spanish mare clausum); the preparation of hydrographic charts to improve navigation; and a confidential examination of political and social conditions in the Spanish provinces. Included in the secret tasks of the expedition were the preparation of comprehensive political reports on the new Russian and English settlements in the North and South Pacific. ${ }^{1}$

During their stay at Port Jackson, the Spanish officers duly collected as much information as possible relating to the purpose and conditions of the 'Botany Bay' colony, both from direct observation and from published sources such as Watkin Tench's $A$ narrative of the expedition to Botany Bay, and John White's Journal of a voyage to New South Wales. This information was put together in a document entitled 'Apuntes sobre la Colonia Inglesa de Puerto Jackson', and in a report composed by Malaspina entitled 'Examen Politico de las Colonias Inglesas en el Mar Pacifico'.2

Both the 'Apuntes' and the 'Examen' devote some paragraphs to a description of the Aboriginal people (the Eora) of the Port Jackson area, and comment on the state of relations between them and the English settlers. Though not to be compared in value to David Collins's Account of the English Colony in New South Wales, Malaspina's 'Examen' and 'Apuntes' are the only non-English record of this period, and as such provide a valuable check on Collins and the other British writers who described the Aborigines. The portraits made by the expedition's artist, Juan Ravenet, are among the best representations ever made of the Eora of this period. ${ }^{3}$

Robert King is interested in the Anglo-Spanish rivalry in the Pacific which formed the background to English settlement of New South Wales in 1788. He is currently preparing for publication Malaspina's report on his expedition's visit to Port Jackson in 1793.

1 Malaspina and Bustamente 1788.

2 Malaspina 1793a; Malaspina 1793b.

3 Ravenet 1793. 'Eo-râ' was 'the name common for the natives' according to David Collins, who made an attempt to learn their language. Collins 1794:611. 
Malaspina's interest in the Port Jackson colony was first and foremost strategic. He saw it as a threat to the Spanish possessions in the Pacific (as has been explained elsewhere ${ }^{4}$ ). His observations on the Aborigines were incidental to his main purpose of determining the real motives of the British Government in founding the colony and how Spain should react. He felt deeply outraged, as any Spaniard of that era would, at the effrontery of the English in intruding into Spain's mare clausum, the Pacific. Spaniards felt they had been given a divine mission to Christianise the New World and bring its peoples into the comity of civilised nations. Malaspina compared the reasons given by the Government in London for the Botany Bay project with the actual situation existing at Port Jackson. He stated the conclusions of his analysis as follows:

If we are convinced therefore from the preceding reflections that, although the object of the present measures was solely to secure a double victory to the weighty arm of Justice, of a great improvement of those who had offended her, and of a great warning to those who intended to offend her in the future, far from bringing this about, they have rather given new resorts to Injustice, and to oppression; and have opened a field through which in not much time the individuals who, whether because of their bad education, or because of deficient State policy, could disturb so much the interior peace of Great Britain, can now with impunity menace with their depredations the entire World, and in particular the peaceful Inhabitant of the Isles of the Pacific.

But these are not reflections which could have been hidden from the British Government when, the impossibility of an establishment of this sort on the Coast of Africa having been made public by the reports of an exploratory Frigate, it apparently decided instantly, and without any trial, in favour of New Holland; and they solely appeared negligible because they should produce, as well as the increase already indicated of commerce and of dominion, an active war in the Pacific.

Tranquil Inhabitants of its immense shores ... how can you imagine at this moment that the present of a few ribbons and Trinkets, the useless gift of a few Domestic animals, and astronomical observations a thousand times repeated, will very soon have brought to you a scene of Blood and Destruction? ... The smallness of their Islands, the Coral Reefs which surround them, the small utility and scarceness of their Fruits, nothing will suffice to protect them from the vices and greed of the Europeans. 5

The accuracy of Malaspina's deduction of the real motives of the British Government in establishing a colony on the east coast of New Holland has been examined elsewhere. ${ }^{6}$ Essentially he was correct. The British did aim to open up a new continent for European civilisation and the benefit of British commerce, as they had earlier opened up North America; but it was no accident that Phillip's expedition was sent off at a time when the renewal of war with Spain, France and Holland appeared imminent. The advantages of a base in New South Wales in case of such a war had been clearly stated by the proponents of the 
colony, and naval and military plans drawn up during wars and crises with Spain before and after the colony was established, for a raid across the South Pacific against Chile and Peru, showed how it would be used as a port of shelter and refreshment. The wishes and rights of the miserable New Hollanders were a minor consideration in this scheme of things.

The English colony at Port Jackson had been established for just over five years when the Descubierta and Atrevida dropped anchor in Sydney Cove. The Aborigines of the Port Jackson area, the Eora (or 'Iyora') as they called themselves, had tested and felt the strength of the Bereewalgal - the 'people from afar'. An epidemic of smallpox was estimated to have reduced the Eora population by half to about a thousand individuals. Other diseases brought by the English ships, and depredations by the settlers on their fish and other food resources, had probably also contributed to this decimation. The tribe or clan of thirty to fifty people who had lived on the peninsula ( $k a t t a i)$ between Sydney Cove and South Head, the Cadi-gal, had been virtually extinguished by these causes. After an initial period of intense hostility, the Eora had apparently come to terms with the futility of trying to resist the newcomers.

The turning point in English/Eora relations came with the incident on 7 September 1790 when Phillip was speared by Willemering at Kayemai (Manly Cove). Phillip accepted that Willemering had flung his spear in a moment of panic, and forbade any retaliation. Both Bennelong and Colbee had been present at the incident, and on the next occasion when they and their families were in the vicinity of Sydney Cove, they were reassured with a present of thirty or forty large fish.

The confidential visit [said Captain John Hunter] from two men, who appeared to have some influence among their countrymen, soon brought about a more general intercourse, and the next visit from those men brought the same favour from their wives and families, whose example was followed by many others; so that every gentleman's house was now become a resting or sleeping place for some of them every night; whenever they were pressed for hunger, they had immediate recourse to our quarters, where they generally got their bellies filled.

Hunter added that before he left Port Jackson, in March 1791, the Aborigines had become 'very familiar and intimate with every person in the settlement; many of them now took up their rest every night in some of the gentlemen's houses; their very unprovoked attack on the governor and his party being passed over and almost forgot'.

Writing of April 1792, Collins said:

The natives had not lately given us any interruption by acts of hostility. Several of their young people continued to reside among us, and the different houses in the town were frequently visited by their relations. Very little information that could be depended upon respecting their manners and customs was obtained through this intercourse; and it was observed, that they conversed with us in a mutilated and incorrect language formed entirely on our imperfect knowledge and improper application of their words. 8

A year later, Malaspina gave a corroborating description of relations between the English and the Aborigines. After describing the basic incompatibility of the two, and the great mortality caused by the smallpox, he felt constrained to admit that the measures taken by the English for the civilisation of the Aborigines had been humane and prudent. The Spanish

Hunter 1793:143.

8

Collins 1798:209. 
officers had seen Aboriginal men and women admitted to the houses of the principal individuals of the colony, where they had been regaled at table with the other guests. Families of Aborigines had cheerfully greeted the Spaniards in English, and on occasion they had been observed singing and dancing the whole night long around campfires in the main streets of the settlement, without anyone molesting them.

David Collins summed up the situation in September 1796:

after many untoward occurrences, and a considerable lapse of time, that friendly intercourse with the natives which had been so earnestly desired was at length established; and having never been materially interrupted, these remote islanders have been shown living in considerable numbers among us without fear or restraint; acquiring our language; readily falling in with our manners and customs; enjoying the comforts of our clothing, and relishing the variety of our food ... They have been always allowed so far to be their own masters, that we never, or but rarely, interrupted them in any of their designs, judging that by suffering them to live with us as they were accustomed to do before we came among them, we should sooner attain a knowledge of their manners and customs, than by waiting till we had acquired a competent skill in their language to converse with them ... By slow degrees we began eventually to be pleased with, and to understand each other. Language, indeed is out of the question; for at the time of writing this, nothing but a barbarous mixture of English with the Port Jackson dialect is spoken by either party; and it must be added, that even in this the natives have the advantage, comprehending, with much greater aptness than we can pretend to, every thing they hear us say.

The picture given by Collins was corroborated by Louis de Freycinet, a French naval officer who visited Port Jackson for five months in 1802 with the Baudin expedition. Freycinet edited the official report of the expedition which was written by François Péron. Commenting on Péron's division of the colony's society into two classes, the free and the condemned, Freycinet noted:

One could add to this the indigenes; but these latter who are few in number and live with the English on fairly good terms, have not yet been brought to the first beginnings of civilization. The English leave to these savages all liberty to follow their inclinations and habits, and never attempt to enslave them, seldom have they been obliged to safeguard themselves against their blows, even at the original foundation of the colony. ${ }^{10}$

Writing in 1806 to his successor, William Bligh, Governor King said, concerning the Aborigines: 'Much has been said about the propriety of their being compelled to work as Slaves, but as I have ever considered them the real Proprietors of the Soil, I have never suffered any restraint whatever on these lines, or suffered any injury to be done to their persons or property'.11

9 Collins 1798:543-4.

10 Péron and Freycinet 1816:394.

11 King 1806. 
Both King and Collins had held positions of responsibility in the colony from its establishment in 1788, and their views may be taken as reflecting the official outlook. The record left by Malaspina confirms the picture we have from other sources of well-intentioned but clumsy and even self-defeating efforts by the English settlers to gain the goodwill of the Aborigines while occupying their lands: the Eora powerless to prevent this 'usurpation' of their rights (as Malaspina referred to the process of English colonisation in his report) but unwilling and unable to give up their own way of life and become 'civilised' as the Europeans wished. In the Sydney of the 1790s, English and Eora dwelt side by side, in a kind of uneasy peaceful coexistence. That there was a high degree of social interaction between the two is shown not least by the fact that most of the Aboriginal words which have come into English did so during this period from the language of the Eora. Malaspina's account of the Aborigine who asked his English friend to make a present of a duck he had bagged to the visiting Spaniard is a nice illustration of the personal friendship which could exist at this period.

\section{Background to the 'Examen' and 'Apuntes' Accounts.}

Malaspina was born, of an ancient noble family, on 5 November 1754 in Mulazzo in the Duchy of Parma. He grew up and was educated at Palermo in the Bourbon Kingdom of Naples, and joined the Marine Guard of Cadiz in 1774. Commissioned frigate captain in 1782, he commanded the Asuncion in a voyage to the Philippines in 1783-84, and subsequently the frigate $A$ strea in a voyage around the world in 1786-88. Conceiving the idea of a 'politico-scientific' voyage of investigation of the Spanish possessions in the Americas and the Pacific, he worked on the plan for this with his partner Bustamente, and on 30 July 1789 set sail from Cadiz as Captain of the Descubierta and senior commander of the expedition. 12

Because, after his return to Spain, he fell victim to the intrigues of Godoy, the findings of the expedition, which Malaspina had estimated would have filled seven volumes when published, were placed under a ban and consigned to the archives.

An abbreviated account of the voyage, consisting mostly of Malaspina's 'Diario de viaje'13 was published in 1885 in Madrid by Pedro de Novo y Colson. ${ }^{14}$ Malaspina's 'Diario', edited by Mercedes Palau, Aránzazu Zabala and Blanca Sáez, was republished by the Museo Naval in $1984 .{ }^{15}$ The journal of another officer of the expedition, Francisco Xavier de Viana, was published in Montevideo in 1849. ${ }^{16}$

The portions of Viana's Diario and Novo's Viaje relating to the visit of Descubierta and Atrevida to Port Jackson were republished in translation, together with Malaspina's letters written in 1789 to Sir Joseph Banks and David Collins's account of the visit, by the Australian Documentary Facsimile Society in 1967 under the title The Spanish at Port Jackson: the visit of the corvettes Descubierta and Atrevida, 1793. ${ }^{17}$ Neither the 'Examen' nor 'Apuntes' was included in this work.
12 Aritiguedades...
13 Malaspina 1794.
14 Novo y Colson 1885.
15 Malaspina 1984.
16 Viana 1849.
17 Day et al. 1967. 
ABORIGINAL HISTORY 1986 10:1
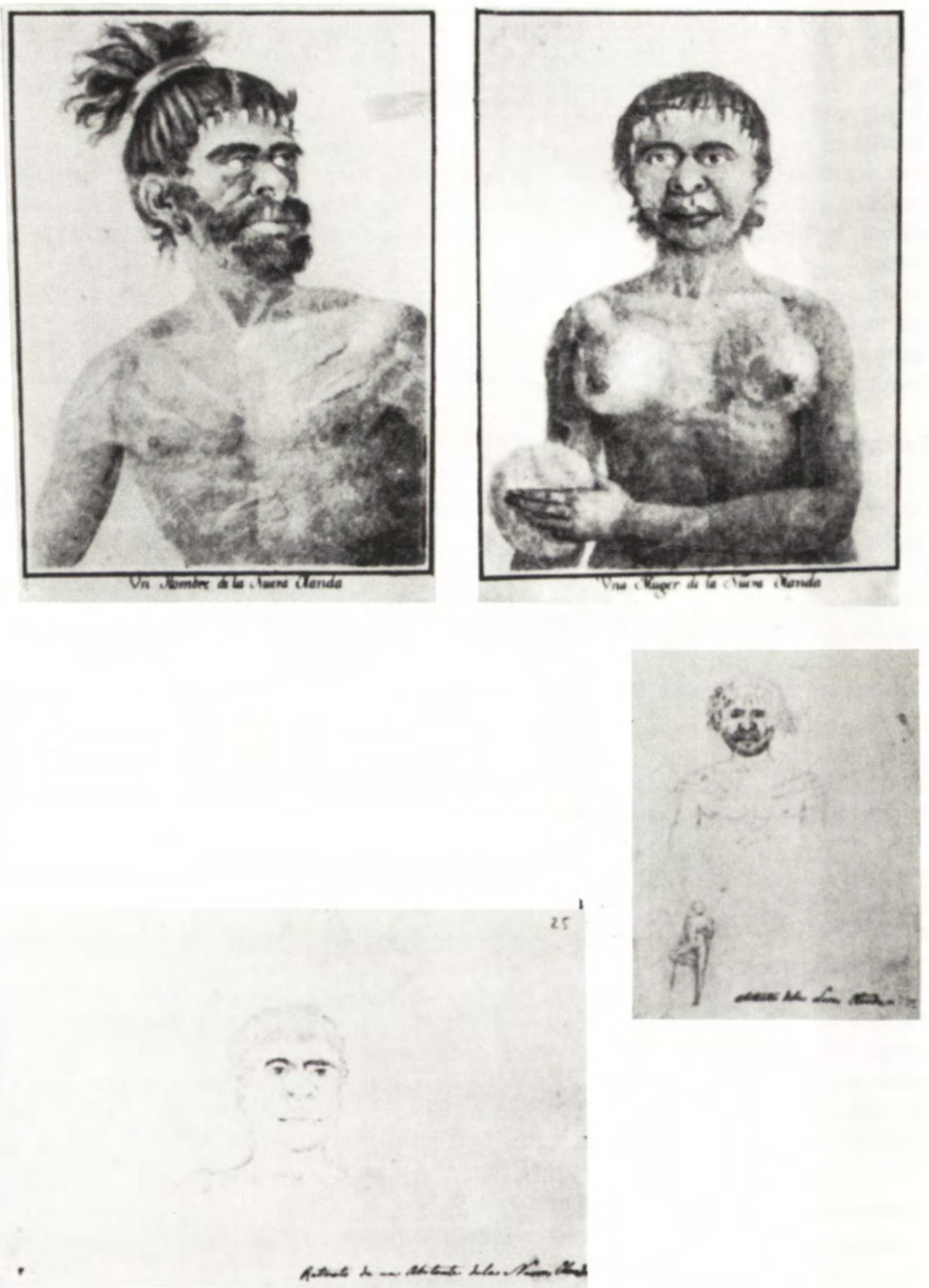

Portraits of three men and a woman of New Holland by Juan Ravenet (Museo Naval, Madrid) 
Although there have been many studies of Malaspina, ${ }^{18}$ very little attention has been given to the visit to Port Jackson. Edith C. Galbraith, in 'Malaspina's voyage around the world, 19 did not describe his visit to Sydney, nor did Iris H.W. Engstrand in her Spanish scientists in the New World: the eighteenth century expeditions. ${ }^{29}$ However, Antonio Giordano did include a short biography of Malaspina and excerpts from Novo's Viaje... and Collins's Account . . . relating to the visit to Port Jackson in his history of Italian explo. ration in the region. 21

Malaspina's 'Examen' and the 'Apuntes' have hitherto been neglected by scholars in the Australian-Pacific field, though they were among the documents in Spanish archives relating to Pacific exploration which were located by Celsus Kelly, OFM. ${ }^{22}$

The sketches and paintings made by Fernando Brámbila and Juan Ravenet while the expedition was at Sydney were published by Carmen Sotos Serrano in $1982 .^{23}$

\section{EXTRACT FROM 'EXAMEN POLITICO DE LAS COLONIAS INGLESAS EN EL}

\section{MAR PACIFICO', 1793, MUSEO NAVAL (MADRID) MS 318}

The Inhabitants of all these parts are without doubt very small in number, and more inclined to Fishing than the Chase, as being a less painful and less uncertain means of subsistence than that drawn from the latter. The unequivocal proofs of this are, the difficulty encountered by the new colonists in trapping Kangaroos, and in hunting them, in spite of the excellent Dogs with which they pursue them, and the marks in the trunks of the trees, referred to by Sir Joseph Banks, and seen by us almost daily, which show how much cost in time and fatigue it takes at other times to procure for themselves the miserable meat of a single bird, not seldom quicker than the Pursuers themselves, by which they are made mock of. This scarcity of Food should then have influence, and actually does have influence, not only in the small proportions of their bodily structure, and particularly in their inferior size,${ }^{24}$ but also in the absolute lack of strength which the English acknowledge after a thousand trials of every kind of Labour including even the softest.

These qualities, united to the total lack of ideas, of activeness, of shelter, of desires, and of Luxury, suffice of themselves to make not reckless the proposition that it would be better for the English to remove them from these parts, than make them useful for future mutual

18 Camponi 1862; Caselli 1919/1929; Bona 1931 and 1935.

19 Galbraith 1924.

20 Engstrand 1981.

21 Giordano 1974.

22 Kelly 1965:362. For discussion of the 'Examen' see R.J. King 1981:71-89.

23 Sotos Serrano 1982.

24 Don Juan Ravenet, fearing to incur the accusations which many erudite Europeans had brought against the Painters of Captain Cook, the Messrs. Forster, of representing in their designs rather the beautiful Figures of the Greek School than the natural constitution of badly nourished Savages fed on perpetual idleness, has blindly followed exactitude in his portraits in the same manner which he has displayed in all the other works he has done up till now [orig. footnote]. 
Prosperity; but besides this are added two other circumstances, which do not appear in any way insignificant. The first is their treachery in taking unawares and killing immediately whoever carelessly goes inland without Arms; also from the habit, which we have already referred to, of burning the countryside; a habit which caused equal concern to Captain Cook at the Endeavour River and to the recent arrivals at Sydney Cove: and the second is the great mortality lately caused them by a violent epidemic of smallpox.

Wary to avoid the accusation of this being the first fruit of their coming to these distant regions, the English allege in their favour that the epidemic manifested itself at almost the same time as their arrival, stating on the other hand legally that in all of the First Fleet there had not been anyone who had carried it; that they found it distinguished among the Natives with its own name; and that finally either this sickness was known before the coming of the Europeans, or that its introduction must have been brought by the French Ships of the Comte de la Perouse. It would be an idle rashness to wish now to entertain ourselves by examining this question: for our purpose it suffices to demonstrate that what will be easier and sooner will be the destruction rather than the civilisation of these unhappy people.

We should not hide, however, the fact that the measures taken by the English for their civilisation have been quite humane and prudent. We have seen gathered and cared for with the greatest kindness, several Boys and Girls. Others, both men and women, although entirely naked and disgustingly dirty, have been admitted to the same Room where we were eating and have been regaled with one or other dainty from the same Table. At times we have heard entire Families salute us with several shouts in English; at times in the principal Streets of the Colony itself they have danced and sung almost the whole night around a campfire, without anyone molesting them. But, whether or not they are able to combine with the sociable Instinct of Man other such strange contradictions, it is certain that, similar to the Hottentots, the young adults at times suddenly quit the house where they are being fed, and the clothing which covers them in order to return to their own to continue their primitive wandering life, divested it would appear of all sociable attraction.

\section{EXTRACT FROM 'APUNTES SOBRE LA COLONIA INGLESA DE PUERTO} JACKSON', 1793; MUSEO NAVAL (MADRID), MS 181

The Negritos of New Holland described by Capt. Cook are the most miserable and least advanced nation which exists on earth. We are not able to give an idea of their customs or rites, nor of their state of society, as we would wish: our deficiency in the European Language of the country and the lack of opportunities for informing ourselves constantly hindered our investigation; but we will explain simply and with our habitual impartiality whatever occasion has permitted us to observe of them in person at the times when we have had dealings with them, which did not happen to be frequent. We quite realise that one can conclude nothing from investigations undertaken at haphazard nor without a set plan, but will confidently attempt to permit to our imagination a freer field than that which our eyes have beheld. The English nation, disposed toward these kinds of observations by inclination and by character, have already advanced in the subject as much as one could desire: we lack that information and only promise to advance some ideas which may serve as a check on the way we look at things, exposed always to the errors of the weakness of our imagination, and of 
confusing the Indigenous customs with those which have been imperfectly adapted from the Europeans.

This wandering Nation, without agriculture and industry, and without any product which would attest their rationality, frugal by necessity and timid by character, received the first Europeans without surprise albeit with some admiration, but neither the strangeness of colour, nor clothes, nor arms, nor whatever means devised by Capt. Cook to arouse their cupidity, nor the efforts of European Artfulness, excited their imagination or covetousness, and at the end of many days he saw with surprise that they abandoned the same articles which they had been made gift of: doubtful of their rationality and at the same time confusing them by their shape with the Orangutans of Africa, he redoubled his efforts to gain a meeting, with little result. Having a lively character, a language exceedingly soft, and enough sharpness, they do not make any exertion of their talent and at the same time are the only nation which does not manifest in either of the Sexes seen any Shyness, nor of having acquired viciousness in exchange for their original grace. Completely naked, without a single thread on their Bodies, neither has the continued contact with Europeans succeeded in increasing their dislike as far as horror of this custom. Men, Women, Youths, children, all present themselves in the streets, or by themselves or in groups, in the same fashion in which they were born, and if sometimes they are seen evincing some repugnance to wearing clothes, they nevertheless love clothing when it is cold, but stupidly throw it away or put it aside when it hinders them.

The figure in both sexes is quite refined: the men are small, of a burnt black colour, the skin roughened by the weather, a little hairy, the Head thickly covered with curly hair, but not lank, beard curly and badly parted, eyes black, round and penetrating, features coarse, nostrils quite wide, the mouth large and thickly whiskered, a weak musculature with little strength, a large belly, thighs and calves short, slender and bowed, the arms and shoulders adorned with seams made in the skin arranged in disorder.

The Women, without a better body than the men, enjoy it would appear a more robust constitution: the faces finer, breasts perfectly formed, almost rounded, elastic and separated, the belly equally rounded, thighs and calves generally more robust and better proportioned than the men's, hips much narrower and regular than those of our European women, their skin in contrast tanned in all parts, and in addition those who have given birth do not remain wrinkled and ravaged like our women; the pubis extremely deep and with a thick growth of hair, and that figure they owe perhaps to a practice, used only by licentiousness among other nations, of leaving to the females the superior position in copulation. From girlhood they cut off one of the little fingers, and their fecundity appears to be much in advance of the other sex. In them one sees how much the beautiful formation of unaided nature exceeds that of art. A well-formed European woman put to examination without any greater adornment than the islander would be made to see what disorders a dress laced up viciously from infancy is capable of causing in our scheme of things.

Their rites are composed of various superstitions, upon which we are not informed. It appears that they are allowed only one wife and several concubines, requiring of them respect for the others. Each family, comprising one man, his wives and his children, form a separate tribe. We do not know how far the faculties of the chief extend, nor at what stage of life the sons proceed to form a new family. Jealousy does not appear to be a passion known in these regions: the females prostitute themselves easily (perhaps this is a vice acquired from contact with Europeans). They are allowed to go freely wherever they wish, 
and they themselves make all the efforts to offer themselves: for my part I have seen them in this case only twice, on both there were no men of their kind there, and the offer of all of them fell always on the youngest; I do not know whether in order to consider advantages in that circumstance, or in order not to allow this liberty to their husbands. But it would require a total depravity of sensibilities to suffer the smell, the slovenliness and the roughness of their gross caresses: few women in the universe could present themselves in conditions which would cause an effect so contrary to their desires. However, it happens that such is the desire for novelty and the depravity of tastes in a free country where prostitution is so common, and where nothing is as easy as the means of satisfying every kind of voluptuous passion, that the English lower orders do not disdain them, and each night a large number of them are gathered in the quarters of the troops.

Parental love does not extend its force as far as among other savages: the gifts given to a father for his little sons never reach their destination; and several infants have been seen feeding at the breasts of many mothers. Several pretend that among them they have ideas of revelation, of the flood and of transmigration: what is certain is that they are extraordinarily distressed when they recall to themselves their dead.

In spite of their sobriety they live happily: ordinarily one comes across them dancing. Alike in this to the Guineans, they express the sensuality of their desires in their songs and attitudes. The vibration of their knees, the vigorous rubbing of the most sensitive parts, and the other movements of each sex, with the ardour which may be observed in their features, are other such unequivocal signs of what they express. Their abode is on the beaches and in the Woods: the thick trunk of a tree, or the crevice in a cliff, lodge each family, who withstand the storms and cold without any other aid to oppose them than their skins. Their foods are roots and fish, and so they live as well in the Woods as by the sea, but even in these practices their industry is sensible of its own small vigor. Two or three yards of the bark of a tree scarcely an inch thick, folded at the ends to make a concave figure, is a Boat sufficient for three women, one of whom occupies herself with bailing out the water which enters continually, while the others row with small paddles, with shells or merely with their hands. A fire which is placed on sand moves to and fro among the women, and their skins which are proof against the elements are also incombustible. Hooks formed from the lip of a seashell, and gaffs made solely of wood are their gear for getting fish, which they devour scarcely warmed on the embers, as if they are always hungry, and put in their insatiable bellies whatever they come across - Bread, a Cob of Maize, and even a tallow candle are delicious foods, but nothing equals a Biscuit dipped in salty water, which is the most agreeable to them: they know it by the name 'Berriguet', not being able to pronounce its English name.

They keep generally good harmony with the Europeans: punishment has made them cautious in this regard; there are very few tribes which do not maintain a strict subordination to the English, and the inequality in arms has extinguished or removed the discontented. The mere sight of a musket, the appearance of the uniform of a soldier, would scatter an army of natives, who with signs of peace and submission take pains to capture their goodwill - in contrast to their behaviour towards the unarmed citizen travelling by himself, several of whom have been the victims of their lack of precaution. It is not our intention to dwell upon the origin of this dread, or to be either the critic or the apologist for the humanity of the Europeans in the Southern Wales: this has been argued about with enough injustice in the case of America. Happily, the enlightenment and the reflections of Europe will protect them against excessive criticisms; and also several accounts which we received in the country have 
given sufficient room to justify us; we are far from proceeding to lightly adopt hostile views, and we scorn whatever has not been compared.

Their arms are composed of an ill-formed machete and a lance of wood hardened by fire or tipped with flint, at any rate a weak help, and infinitely less valuable than ours. The stupidity of the natives is such that they are unable to draw any profit for themselves, contact with the Europeans having merely contributed to increasing their needs without thereby stimulating them to supply the means of satisfying them: they take and ask for what one would give them without any labour; at the most some serve as domestics but without any ability, and work less than it takes to keep them clothed. When we arrived they could not understand that we spoke another Language than English, and the most they could comprehend was that we did not understand how to speak. However, they were treated with openness and thanks to several gifts we merited equal affection with the English. They are appreciative enough to those who treat them well, and one of their greatest courtesies is that of exchanging names and they keep them until they are supplied with a new change. They are exceedingly lively, and in their actions and movements use a thousand stratagems when they wish to be given something, and imitate Monkeys in their gracefulness. When one of our officers was presented by an Englishman to an Indian Friend of his, he was most friendly toward him, and not having anything to present as gift to him he asked the Englishman for a Duck which he had caught to present to our comrade, saying that it was necessary to give something to the visitor.

Their Language is exceedingly soft, each word consists of many Vowels, they pronounce it with incredible volubility, and in an agreeable tone, which seems more like well-composed music. They speak the English Language but in an imperfect way, softening the Gutterals, and they never pronounce any word strongly.

\section{BIBLIOGRAPHY}

Antiguedades de los oficiales de guerra de la Armada. Museo Naval, Madrid, MS 1161.

Bona, Emma. 'Sulla vita ed i viaggi di Allessandro Malaspina di Mulazzo'. Bollettino Reale di Società Geografica Italiana, Ser. 6, Vol.8, gennaio 1931. Alessandro Malaspina, sue navegazioni ed explorazioni. Rome, 1935.

Camponi, Giuseppe. Della Vita e della Avventura del Marchese Alessandro Malaspina. Modena, 1862.

Caselli, Carlo. Alessandro Malaspina e la sua spedizione scientifica intorno al mondo. Milan, 1919 and 1929.

Collins, David. An Account of the English Colony in New South Wales. Vol.I. London, 1798.

Day, A. Grove, Virginia M. Day, Iris Burke, and Keast Burke. The Spanish at Port Jackson: the visit of the convettes Descubierta and Atrevida, 1793. Sydney, 1967.

Engstrand, Iris H.W. Spanish scientists in the New World: the eighteenth century expeditions. Seattle, 1981.

Galbraith, Edith C. 'Malaspina's voyage around the world', California Historical Society Quarterly, 3(3), 1924:215-237.

Giordano, Antonio. Marco Polo ... and after: a brief survey of Italian travel and exploration in South East Asia, New Guinea and Australia. Adelaide, 1974.

Hunter, John. An Historical Joumal of the Transactions at Port Jackson and Norfolk Island. London, 1793.

Kelly, Celsus. Calendar of documents: Spanish voyages in the South Pacific from Alvaro de Mendăna to Alejandro Malaspina, 1567-1794 . . Franciscan Historical Studies, Madrid, 1965.

King, Philip Gidley. Letter to William Bligh, 1806. Mitchell Library, King Papers; quoted in Jonathan King, Philip Gidley King, Sydney, 1981, p.135. 
King, Robert J. 'The territorial boundaries of New South Wales in 1788', The Great Circle, 3(2), 1981: 70-89.

Malaspina, Alexandro. Apuntes sobre la Colonia Inglesa de Puerto Jackson. 1793a. Museo Naval, Madrid, MS 181.

Examen Politico de las Colonias Inglesas en el Mar Pacifico. 1793b. Museo Naval, Madrid, MS 318, ff.11-37.

Diario de viaje. September 1794. Museo Naval, Madrid, MS 753.

Diario de viaje, eds Palau, Mercedes, Aranzazu Zabala, and Blanca Saez. Madrid, 1984.

Malaspina, Alexandro, and Josë de Bustamente y Guerra. Plan de un viage cientifico y politico a el rededor del mundo, remitido a el Ex. mo S.I Baylio Fray Antonio Valdez de Madrid en 10 Sep ${ }^{t}$ de 1788. Museo Naval, Madrid, MS 316.

Novo y Colson, Pedro de. Viaje politico-cientifico alrededor del mundo por las corbetas Descubierta $y$ A trevida, al mando de los capitanes de navio, don Alejandro Malaspina y don José de Bustamente y Guerra, desde 1789 a 1794. Madrid, 1885.

Péron, Francois, and Louis de Freycinet. Voyage de decouvertes aux Terres Australes, executee sur les corvettes le Geographe, le Naturaliste, et la goelette le Casuarina pendent les annees 1800, 1801, 1802, 1803, 1804. Paris, 1816.

Ravenet, Juan. Dibujos, 1793: 'Estudio de Actitudes de los Habitantes de la nueva Holanda', 215 x 160 mm pencil. State Library of New South Wales, Bauzá Collection, II(2), p.54, no.128 (DG D2).

'Una Muger de la Nueva Olanda', 290 x 395 mm, pencil. Museo Naval, Madrid, carp.1-29.

'Un Hombre de la Nueva Olanda, 285 x 395 mm, pencil. Museo Naval, Madrid, carp 1-28.

'Retrato de un Abitante de la Nueva Olanda', 200 x 310 mm, pencil. Museo Naval, Madrid, carp. 1-25.

'Nueva Holanda - Cabeza de un habitante', 114 x $160 \mathrm{~mm}$. State Library of New South Wales, Bauzá Collection, II(1), p.28, no.64 (DG D2).

Sotos Serrano, Carmen. Los Pintores de la Expedición de Alejandro Malaspina. Madrid, 1982.

Tench, Watkin. A narrative of the expeditions to Botany Bay, with an account of New South Wales, its productions, inhabitants, etc., to which is subjoined a list of the civil and military establishments at Port Jackson. London, 1789.

Viana, Francisco Javier de. Diario del Viage Explorador de las Corbetas Espanolas 'Descubierta'y 'Atrevida' en los anos de 1789 a 1794. Cerrito de la Victorià, Uruguay, 1849.

White, John. Journal of a voyage to New South Wales. London, 1790. 